\title{
The usability of industrial wastes on soil stabilization
}

Ismail Zorluer (Main and Corresponding Author)

Afyon Kocatepe University, Department of Civil Engineering

ANS Campus 03200 Afyonkarahisar (Turkey)

izorluer@aku.edu.tr

Suleyman Gucek

Afyon Kocatepe University, Department of Civil Engineering

ANS Campus 03200 Afyonkarahisar (Turkey)

sgucek@aku.edu.tr

Manuscript Code: 1485

Date of Acceptance/Reception: 22.03.2020/19.05.2019

DOI: $10.7764 /$ RDLC.19.1.80

\section{Abstract}

Soils are made stronger and more durable by mixing additive materials. In particular, the use of waste provides environmental and economic advantages for this case. Wastes form in large quantities, however, which creates storage problems. To objective of this study is to research the availability of industrial wastes for soil stabilization. An experimental study was conducted on granular soil specimens mixed with industrial wastes such as marble and granite dust, boron waste, and fly ash in different ratios. Each mixture used two waste materials together. Specifically, fly ash was used with three additional waste materials because of its pozzolanic characteristics. The tests performed included freezing-thawing, unconfined compression strength, and California bearing ratio. The results of the study show that the strength of a specimen is dependent on the additive ratio, curing period, and the number of freeze-thaw cycles. Generally, unconfined compressive strength and California bearing ratio increased with additive materials and curing times. After freezing and thawing, unconfined compressive strength (except granite dust) decreased, whereas weight loss increased due to increasing additives and increasing freeze-thaw cycles.

Keywords: Soil stabilization, environment, marble dust, granite dust, boron waste, fly ash.

Introduction

Soil stabilization brings the properties of the soil to the required conditions for building. Among other reasons, soil stabilization is executed to increase bearing capacity or reduce settlement, water permeability, or risk of liquefaction. There are many soil stabilization methods, such as mixing additive materials into the soil. These additive materials bond the soil grains, filling gaps and modifying soil properties to the desired level. Industrial wastes such as lime, cement, bitumen, fly ash (FA), marble dust (MD), granite dust (GD), boron (BR) dust, and others can be used for the mixture.

Vast amounts of industrial wastes pose a risk of environmental pollution as well as storage problems. The use of these wastes as additives for soil stabilization can therefore reduce environmental pollution and gain economic advantages.

FA forms as the result of the combustion of coal in thermal power plants to produce electricity. The ash is composed of tiny granules that are emitted from the flue of power plants. The FA is captured filters with and kept in storage areas. FA is used in geotechnical stabilization in a variety of applications, for instance, structural fill, additive material, cover material, in unpaved roads, highway base structures, roadways, and pavement. There are a host of studies performed with FA for soil stabilization. In these works, FA was usually combined with different additive materials such as lime, cement, and industrial wastes (Arora et al., 2005; Cetin et al., 2010; Fauzi et al., 2011; Zorluer et al., 2013; Zorluer \& Demirbas, 2013; Zorluer \& Gucek, 2014, 2017a, 2017b; Verma \& Singh, 2017; Yoobanpot et al., 2017; James \& Pandian, 2018).

$M D$ is a waste which is formed from the sawing process of marble blocks and plates. Because it accumulates in great quantities, MD creates a storage problem. More than $90 \%$ of MD has a grain size smaller than $0.2 \mathrm{~mm}$. Marble dust has been examined as a soil stabilizer in many earlier studies (e.g., Firat et al., 2012; Zorluer \& Demirbas, 2013; Zorluer \& Gucek, 2014; Gurbuz, 2015; Kesvehan et al., 2017; Verma \& Singh, 2017).

Another waste material suitable for soil stabilization is granite dust, which is formed by sawing and processing granite blocks. The blocks are sawed to a thickness of 3 to $5 \mathrm{~cm}$. Water is used to prevent overheating the saw, and tiny granite grains are carried to a sedimentation pond with the water. Several studies with GD have been conducted, 
including research by Ogbonnaya et al. (2011), Zorluer et al. (2013), Zorluer and Gucek (2017b), Misra et al. (2014), Keshevan et al. (2017), and Thirumalai et al. (2017).

BR is a highly soluble material that increases viscosity, toughness, and strength in many materials, reducing radiation, sound, and thermal permeability. For this reason, significant quantities of BR products are produced and used in many sectors. However, the scale of BR production has resulted in a severe solid and liquid waste problem. Solid wastes are discarded in the open, and liquid wastes accumulate in dams (Koyuncu \& Guney, 2003; Zorluer \& Gucek, 2017a). The effects of BR on soil strength have been examined (Zhang et al., 2016; Zorluer \& Gucek, 2017a); however, there are few studies on this subject.

This study examines the effects of industrial wastes on the strength of soil, which is used as a base and subbase material in road construction. Industrial waste materials such as MD, GD, BR waste and FA were used as additive materials. Two or more waste materials were mixed with soil in different ratios.

A pozzolan is a siliceous material that reacts with lime to form cementitious compounds (Sivapullaiah, 2016). FA, in particular, was mixed with three other industrial waste materials because of its pozzolanic characteristics. Unconfined compressive strength values for GD and FA mixtures were obtained from an earlier work by Zorluer and Gucek (2017b), which is part of this study. Specimens were first mixed, then compacted with a standard Proctor energy to mold.

The specimens were cured for 1, 7, 28, and $56 \mathrm{~d}$, and strengths were determined with an unconfined compressive strength test at the end of the curing time. Freeze-thaw (F-T) tests were performed on the specimens at 4,8 , and 12 cycles. Moreover, California bearing ratio (CBR) tests were conducted on the specimens, and several were analyzed with a scanning electron microscope (SEM) to observe the microstructure of the mixtures. Experimental results showed that industrial wastes positively affected the strength of the specimens.

\section{Materials and Methods}

Soil used in this study is granular soil obtained from the Afyonkarahisar municipality, Turkey. This material is used in road construction as a base layer. It had $28 \%$ of particles passing the U.S. No. 10 sieve $(<2 \mathrm{~mm})$, and $8 \%$ passing the U.S. No. 200 sieve $(<0.075 \mathrm{~mm})$. The soil was classified as well-graded gravel (GW) according to the unified soil classification system (USCS) and A-1 according to the American Association of State Highway and Transportation Officials. (AASHTO).

The BR used in this study is waste slime BR obtained from a BR processing plant in Eskişehir, Turkey. The waste BR was dried and sieved from a No. 40 sieve, resulting in BR grains smaller than $425 \mu \mathrm{m}$. The FA was obtained from the Soma B power plant in Manisa, Turkey. The FA is F class according to ASTM C 618 (2003) and W class according to the TS EN 197-1 standard (2002). Approximately, $80 \%$ of the particles are finer than $0.075 \mu \mathrm{m}$.

GD for the study was obtained from a natural stone processing plant in İzmir, Turkey. The GD is generated during the sawing process of granite blocks. The GD is carried by coolant water to a sedimentation pond, where it is removed from the pond, dried, and sieved using a No. 200 sieve. MD was obtained from a marble processing plant in Afyonkarahisar, Turkey. The MD, of which $95 \%$ is finer than $0.075 \mu \mathrm{m}$, was dried and sieved from a No. 40 sieve. Chemical properties of waste materials are shown in Table 1.

\begin{tabular}{lccccccccccc}
\multicolumn{10}{c}{ Table 1. Chemical characteristics of additive materials (\%). Source: Self-elaboration. } \\
\hline & $\mathrm{SiO}_{2}$ & $\mathrm{Fe}_{2} \mathrm{O}_{3}$ & $\mathrm{Al}_{2} \mathrm{O}_{3}$ & $\mathrm{CaO}$ & $\mathrm{MgO}$ & $\mathrm{SO}_{3}$ & $\mathrm{P}_{2} \mathrm{O}_{5}$ & $\mathrm{Ti}_{2} \mathrm{O}_{2}$ & $\mathrm{Na}_{2} \mathrm{O}$ & $\mathrm{B}_{2} \mathrm{O}_{2}$ & $\mathrm{LOI}^{2}$ \\
\hline $\mathrm{BR}$ (Boron) & 21.64 & 0.19 & 0.75 & - & 9.40 & & & 16.77 & 7.88 & 7.75 & 35.38 \\
$\mathrm{FA}$ (Fly ash) & 48.28 & 7.19 & 27.72 & 10.51 & 2.51 & 3.16 & 0.27 & 1.28 & - & - & - \\
$\mathrm{MD}$ (Marble dust) & 0.2 & 0.11 & 0.07 & 54.5 & 0.3 & 0.08 & 0.02 & - & 0.01 & - & 44.52 \\
$\mathrm{GD}$ (Granite dust) & 89.30 & 0.23 & 0.19 & 0.58 & 0.46 & 0.06 & - & - & 0.37 & - & 8.26 \\
\hline LOI: Loss of ignition. & & & & & & & & & &
\end{tabular}

\section{Specimen preparation}

For the specimen preparation, the granular soil was mixed with waste industrial materials (FA, BR, MD, GD) in different ratios. The mixture ratio of additives was obtained from the literature (Zorluer et al., 2013; Zorluer \& Demirbas, 2013; Zorluer \& Gucek, 2014, 2017a, 2017b; Misra et al., 2014; Keshevan et al., 2017; Thirumalai et al., 
2017, Verma \& Singh, 2017). Dry weights of materials were used for the mixtures. The dual use of waste materials was intended to increase the pozzolanic reaction. In particular, FA was selected to mix in different ratios because of its pozzolanic properties. In addition, sample sets were created with mixtures of MD and GD in different ratios.

The optimum water contents were defined and used for the preparation of the mixtures with a standard Proctor compaction energy test. The names of the mixtures and mixing ratios are given Table 2.

\section{Unconfined compressive strength Test}

The unconfined compressive strength (UCS) value measures the strength of the mixtures. The UCS test was performed according to the TS 1900-2 standard (2006). A strain rate of $1 \% / \mathrm{min}$ was maintained during the test. The samples had a diameter of $101.6 \mathrm{~mm}$, length of $116.4 \mathrm{~mm}$, and were compacted using standard Proctor compaction energy in a Proctor mold. Two samples were prepared separately for each mixture ratio. Next, the samples were sealed in plastic wrap three times and covered with a wet cloth to control the humidity. The cloth was wetted every day, and the specimens were cured for $1,7,28$, and $56 \mathrm{~d}$.

Table 2. Mixing Ratio of Specimens. Source: Self-elaboration.

\begin{tabular}{lccccccc}
\hline $\begin{array}{l}\text { Mixture } \\
\text { composition }\end{array}$ & $\begin{array}{c}\text { Granular } \\
\text { soil }(\%)\end{array}$ & $\begin{array}{c}\text { Marble } \\
\text { dust }(\%)\end{array}$ & $\begin{array}{c}\text { Boron } \\
(\%)\end{array}$ & $\begin{array}{c}\text { Granite } \\
\text { dust }(\%)\end{array}$ & $\begin{array}{c}\text { Fly } \\
\text { ash }(\%)\end{array}$ & $\begin{array}{c}\gamma_{\text {dmax }} \\
\left(\mathrm{kN} / \mathrm{m}^{3}\right)\end{array}$ & $\begin{array}{c}\mathrm{W}_{\text {opt }} \\
(\%)\end{array}$ \\
\hline SG & 100 & - & - & - & - & 21.48 & 6.00 \\
SG-5MD-10FA & 100 & 5 & - & - & 10 & 21.09 & 7.10 \\
SG-10MD-20FA & 100 & 10 & - & - & 20 & 20.40 & 7.80 \\
SG-15MD-30FA & 100 & 15 & - & - & 30 & 19.72 & 9.20 \\
SG-5MD-10GD & 100 & 5 & - & 10 & - & 19.91 & 6.80 \\
SG-10MD-20GD & 100 & 10 & - & 20 & - & 19.13 & 9.50 \\
SG-15MD-30GD & 100 & 15 & - & 30 & - & 18.93 & 9.90 \\
SG-5GD-10FA & 100 & - & - & 5 & 10 & 21.00 & 7.20 \\
SG-10GD-20FA & 100 & - & - & 10 & 20 & 19.52 & 8.10 \\
SG-15GD-30FA & 100 & - & - & 15 & 30 & 18.93 & 9.30 \\
SG-5BR-10FA & 100 & - & 5 & - & 10 & 20.50 & 8.20 \\
SG-10BR-20FA & 100 & - & 10 & - & 20 & 19.62 & 9.90 \\
SG-15BR-30FA & 100 & - & 15 & - & 30 & 18.83 & 10.50 \\
\hline
\end{tabular}

$\gamma_{\mathrm{dmax}}:$ Maximum dry unit weight, $\mathrm{W}_{\mathrm{opt}}$ : Optimum water content.

\section{Freeze-Thaw (F-T) Test}

The F-T test is used to determine the effect of winter conditions and the resistance of mixtures under freezing and thawing cycles. F-T tests were performed according to ASTM D 560 (2003). The specimens were compacted in a standard Proctor mold and sealed in plastic wrap, then covered with a wet cloth and cured for $7 \mathrm{~d}$. After $7 \mathrm{~d}$ of curing, specimens were frozen at $-23^{\circ} \mathrm{C}$ or lower for $24 \mathrm{~h}$, and then thawed at $21 \pm 1.7^{\circ} \mathrm{C}$ for $23 \mathrm{~h}$ in a climatic test cabinet.

All surfaces of the specimens were subsequently brushed with a wire scratch brush. In this procedure, one cycle of freezing-thawing was $48 \mathrm{~h}$. Again, the specimens were placed in a cabinet and this procedure continued for 4,8 , and 12 cycles. After the cycles of tests, the specimens were dried and weighed to determine the grain loss of the specimens. The UCS tests were also conducted to determine the effects of freezing-thawing at end of the cycles.

\section{California Bearing Ratio Test}

The California bearing ratio $(C B R)$ test is a penetration test for the determination of the mechanical strength of the highway base materials. The CBR tests were performed according to the TS 1900-2 standard (2003). The specimens were compacted with the optimum water content using the standard Proctor effect on the CBR mold. After compaction, curing was not applied to the specimens, and CBR tests were performed at bottom and top surface of the specimen. The averages of these two values were used for the evolution of the test results.

\section{Scanning Electron Microscopy Analysis}

Scanning Electron Microscopy (SEM) analysis was performed to observe the microstructure of the specimen. SEM analyses were conducted on $56 \mathrm{~d}$-cured specimens. A small part of each specimen was coated with carbon, and its microstructure was examined under the SEM using the energy dispersive X-ray technique. 
Depending on the increase in the additive material, the maximum dry density $\left(\gamma_{\text {dmax }}\right)$ of the specimen decreases and the optimum water content $\left(w_{\text {opt }}\right)$ increases (see Table 2 ). This result reflects conclusions seen in other industrial waste studies (Cetin et al., 2010; Zorluer \& Demirbas, 2013; Zorluer \& Gucek, 2014)

\section{UCS Test}

As seen in Figure 1, the strength increases when the curing period increases for all mixtures. The most significant strength values were obtained with a $56 \mathrm{~d}$ cure time. The strength increased at the same rate for all samples with the exception of the MD specimens, where the strength increase slowed down after $28 \mathrm{~d}$.

According to the type of additive material, the largest strength value was obtained from the 10MD-20FA specimen. The strength value is approximately $4060 \mathrm{kPa}$ at $28 \mathrm{~d}$ cure and about $4200 \mathrm{kPa}$ at $56 \mathrm{~d}$ cure (Figure 1a). In previous studies (Zorluer \& Demirbas, 2013; Zorluer \& Gucek, 2014, Verma \& Singh, 2017), the highest strengths were obtained from a 10MD-20FA ratio for different soils. A strong Pozzolanic reaction occurs between MD and FA; however, this reaction develops quite slowly. As demonstrated in previous studies (Hassett \& Thompson, 1996; Heebink \& Hassett, 2001; Goswami \& Mahanta, 2007), when FA and water combine under alkaline conditions, ettringite forms as a reaction product (Figures $5 \mathrm{a}$ and $5 \mathrm{~b}$ ). Ettringite can improve the physical and engineering performance of soils. Yoobanpot et al. (2017) stated that the formation of a reaction reduced the void ratio of the soil structure, resulting in denser and stronger soil, which corresponds with compressive strength development over time.

For GD-FA mixtures, UCS values were taken from Zorluer \& Gucek (2017b), which is a part of this study. The largest strength value (about $2200 \mathrm{kPa}$ ) was obtained from the 5GD-10FA specimen at $56 \mathrm{~d}$ cure. The strength of the 10GD20FA specimens was also significant (Figure 1-b). Comparable results were obtained from a study by Zorluer et al. (2013), and the greatest strength values were in specimens with 5\%, $8 \%$, and $10 \%$ GD.

For BR-FA mixtures, the most significant strength value was obtained from the 5GD-10FA specimen. The strength is $1230 \mathrm{kPa}$ at $56 \mathrm{~d}$ cure, which is close to the values for 10GD-20FA and 15GD-30FA (Figure 1c). In a study by Zorluer \& Gucek (2017a), the greatest strength value was obtained from a 15GD-30FA specimen, with values about $15 \%$ bigger than this study. This difference in results from the two studies may be due to different granular soil.

The UCS did not increase notably on the MD-GD specimens (Figure 1d). These two materials either do not have a binding property, because they are not pozzolanic material. Therefore, the strength only slightly increased, with the largest strength measured at $380-420 \mathrm{kN} / \mathrm{m}^{2}$ at $56 \mathrm{~d}$ cure.







\section{CBR Test}

CBR test results are seen in Figure 2. The largest values are in GD-FA specimens (between 100\% - 130\%). MD-FA specimens also resulted in high values (90\% - 110\%). When GD and MD are mixed with FA, the strength increases significantly. This means that the mixtures are a good base material for highways. In the BR-FA specimens, CBR values increased slightly (50\% - 85\%). For GD-MD specimens, the strength increase was largely ineffective. Even in the 10MD-20GD specimen, the decrease in the CBR value was substantial. In previous studies (Zorluer et al., 2013, Zorluer \& Gucek, 2017b), the CBR values of GD and GD-FA specimens had decreased.

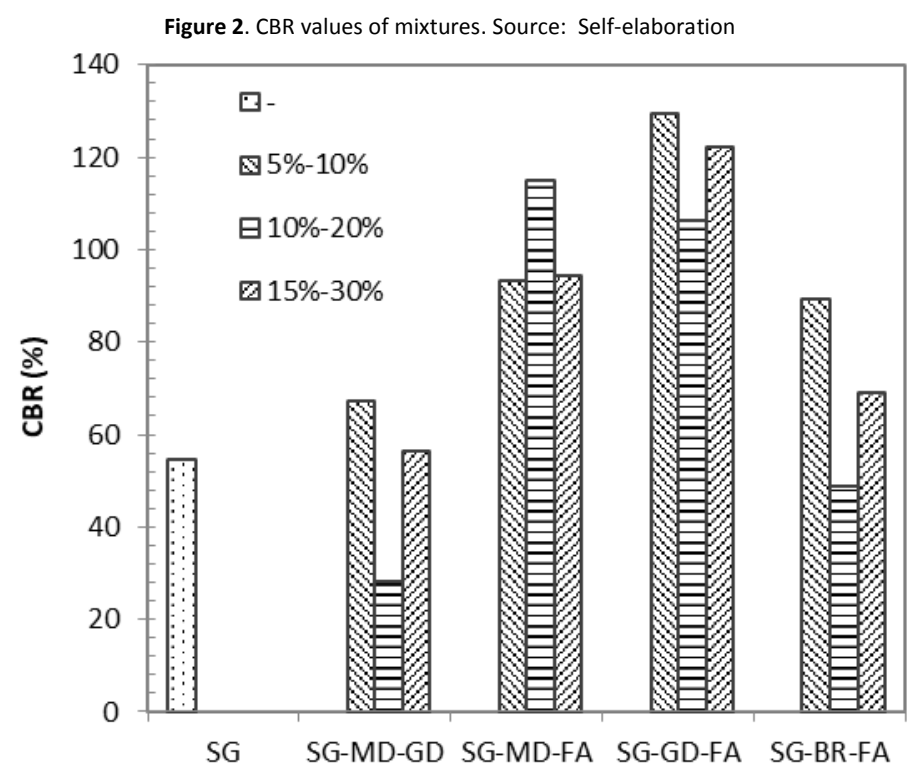

\section{F-T Cycles}

Figure 3 shows specimen strengths after 4, 8, and 12 F-T cycles. Importantly, this test method shows how strength is affected by time and seasonal conditions. The UCS test was performed after the F-T cycles. As seen in earlier studies (Cetin et al., 2010; Zorluer \& Demirbas, 2013), the strength values increased until 8 cycles and then decreased thereafter. The constitution of the decrease resulted from the decline of the bonds formed between particles after a certain cycle. Although all mixture ratios saw a decrease in strength values after 8 cycles, the GD-FA specimens showed a strength increase (and their highest values) after 12 cycles. In a study by Gurbuz (2015), at the end of 12 cycles, the maximum strength was seen in samples with a $10 \% \mathrm{MD}$ additive.

Analyzing strengths after all cycles, it is seen that the largest values are 10MD-20FA, 10BR-20FA, and 5GD-10FA mixture ratios. In another study on MD-FA (Zorluer \& Demirbas, 2013), the maximum strength value was obtained in 
the same mixture ratio, that is, 10MD-20FA. At the same mixture ratio, the maximum strength values were also obtained due to the curing time increase. These two conditions are the determining factor for ideal mixture ratios.


\section{Weight loss after F-T cycles}

A measure of durability is the change in the sample weight after the F-T cycles (ASTM D560, 2003). Eight to 12 cycles are sufficient to assess this strength (Hassini, 1992). Weight loss percentages are shown in Figure 4. Each F-T cycle is followed by a loss of grains from the sample surface. Weight loss increases as the number of cycles increases. The greatest weight loss was observed in the MD-GD samples. Because MD and GD are not pozzolanic, they cannot bind the grains strongly. This situation is clearly seen with an increase in weight loss as the number of cycles and contribution rates increase. The greatest value (17\%) in weight loss was the result of 12 cycles in the 15MD-30GD sample. In contrast, the weight loss of the MD-FA samples was minimal. The weight loss in these samples decreased by $50-70 \%$ compared to the unadulterated samples. In a previous study, Zaman \& Naji (2003) stated that weight loss around $10 \%$ after 12 cycles will not affect the strength significantly. Gurbuz (2015) indicated that the least weight loss was $4.24 \%$, seen in a specimen that added MD $10 \%$ after 12 cycles.

At the end of 12 cycles, the weight loss for the 15MD-30FA sample is around $4 \%$. Also, at the end of 12 cycles, $6 \%$ of BR-FA samples and $9 \%$ of GD-FA samples lost weight. This is due to the pozzolanic effect of the FA. The reaction of FA with other additives increases the binding effect of a mixture, which increases the strength. In the samples with the least weight loss, the strength values obtained were the highest. 
Figure 4. Weight loss of specimens after freezing and thawing. Source: Self-elaboration.

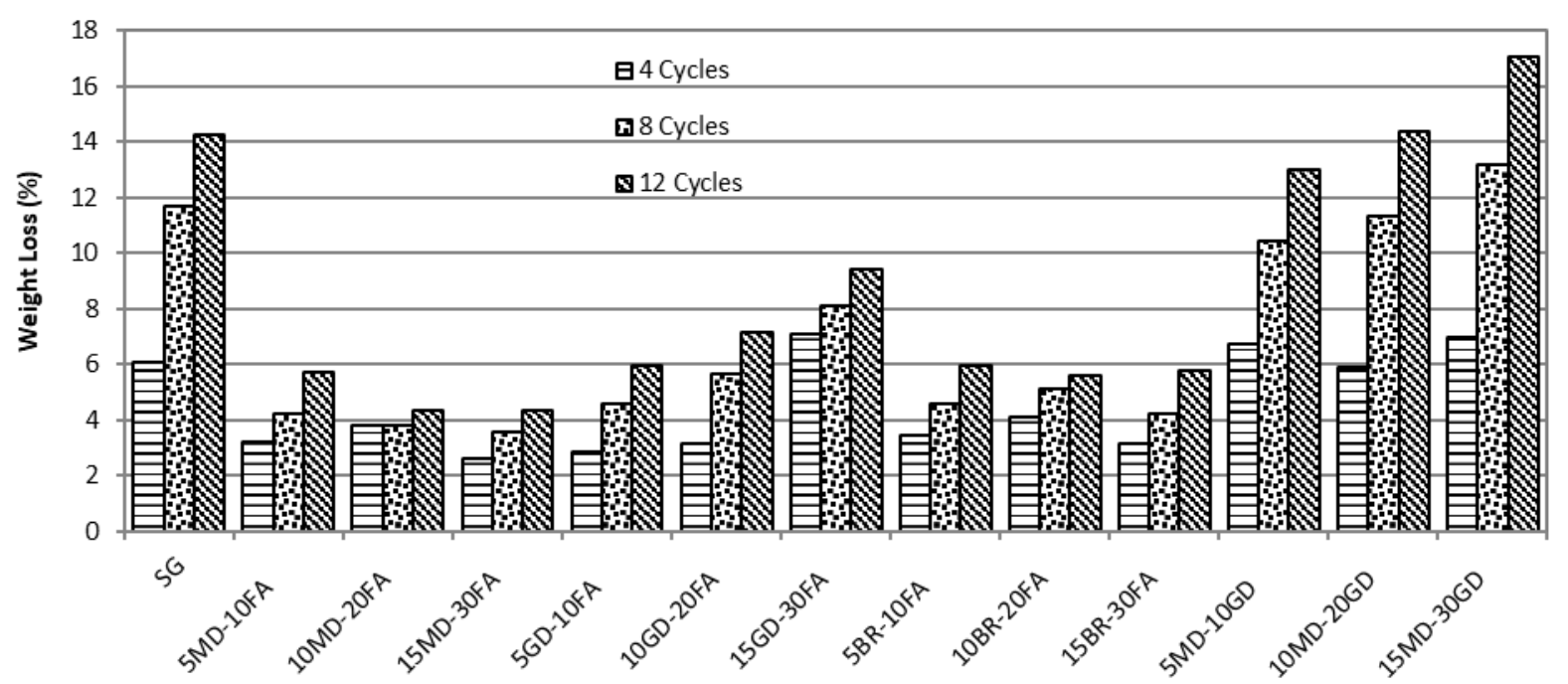

\section{Scanning Electron Microscopy (SEM) Analysis}

In Figure 5, some samples were given SEM images. When MD and FA mixtures are examined in Figure 5a and b, the bonds between MD and FA reaction and granules are seen. The bond around the FA and the ettringite needles on the bond formation is clearly seen. The formation of ettringite can benefit the physical and engineering performance of stabilized soils. Ettringite increases strength and decreases permeability (Hasset \& Thompson, 1996; Heebink \& Hasset, 2001). The pozzolanic reaction from FA was useful in contributing to the higher soil strength (Yoobanpot et al., 2017).

In the BR-FA samples, cementitious grains are visible (Figure $5 c, d$ ). The formation of cementitious material by the reaction of lime with the pozzolans $\left(\mathrm{Al}_{2} \mathrm{O}_{3}, \mathrm{SiO} 2, \mathrm{Fe}_{2} \mathrm{O}_{3}\right)$ the presence of water is known as the hydration of $\mathrm{FA}$. The hydrated calcium silicate gel or calcium aluminate gel can bind material together (Firat et al., 2017). In the soil sample, no texture of the bond is seen (Figure $5 e, f$ ).
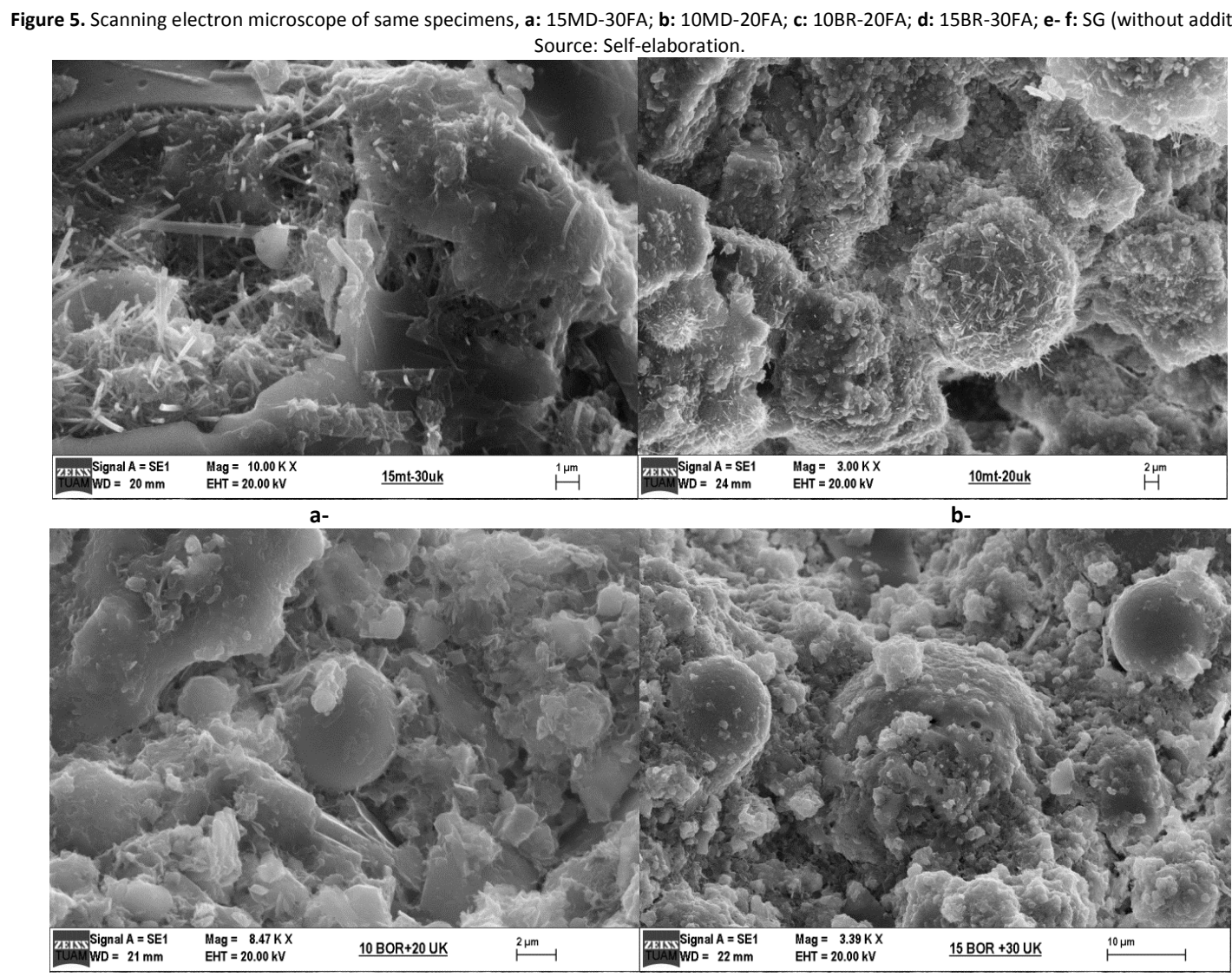


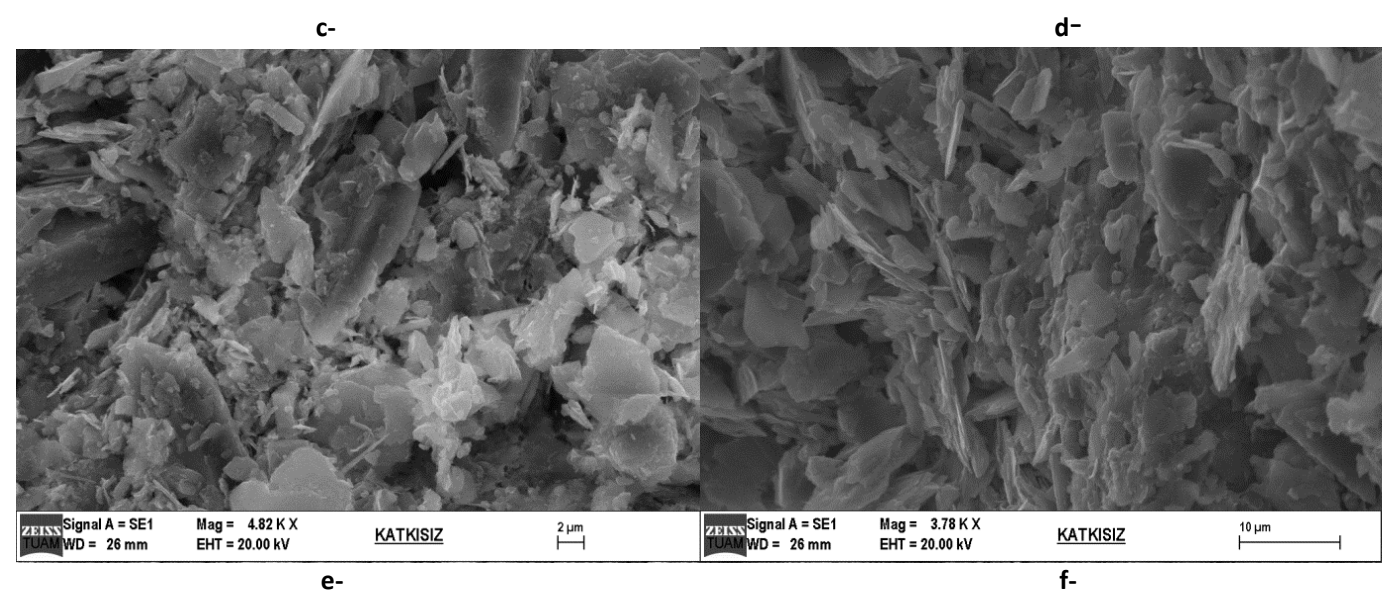

Conclusions

Industrial wastes can be effectively used in soil stabilization. They can also be employed to improve soil properties instead of conventional binders in certain situations. The use of industrial wastes as soil stabilizers can provide significant reductions in costs as well as environmental protection. In this study, the effects of marble dust (MD), granite dust (GD), waste boron (BR) and fly ash (FA) on granular soils was investigated. The results are summarized as follows:

FA gives a more effective result when mixed with another waste, especially with MD. The greatest UCS was obtained from a 10MD-20FA mixture ratio. The highest strength in the GD-FA mixtures was observed in the 5GD-10FA sample, and the highest strength in the BR-FA mixtures was observed in the 10BR-20FA sample. MD-GD mixtures did not show sufficient strength increase. This is due to the lack of pozzolanic properties of MD and GD. Since bond formation does not occur between the grains, there was no strength increase.

The highest value in CBR was observed in the GD-FA mixtures. The MD-FA mixtures resulted in values that were close to the GD-FA strengths. In the BR-FA mixtures, the CBR values increased slightly. However, the CBR values of the MDGD mixtures did not increase, but decreased.

At the end of the freeze-thaw (F-T) cycles, the highest strength was obtained with the 10MD-20FA mixture. After 8 cycles, the strength decreased in all samples except for the GD-FA samples. The strength of the GD-FA specimens increased at the end of 12 cycles. At the end of the F-T cycles, minimal weight loss was observed in the MD-FA mixture and the BR-FA mixtures. Maximum weight loss was seen in the MD-GD mixtures. These values are significant when considering winter conditions.

There is an accordance between tests results. Generally, results of the MD-FA specimens show the highest strength values in the UCS tests, and MD-FA specimens have least weight loss after F-T cycles. However, in CBR experiments, GD-FA samples have higher resistance values than MD-FA samples. This is because there is not cure phases in the CBR tests.

The findings show that MD and GD with FA can be used efficiently on granular soil regarding stabilization applications, such as increasing strength as well as resilience against winter conditions. Note that the optimum usage ratio for FA and MD is 10MD-20FA. BR can also be used for soil stabilization but is not very effective.

Industrial wastes examined for this study have been shown create positive changes in soil properties. This allows for a more economical additive material to be used instead of the binders. The use of waste also contributes to the reduction of environmental pollution. In addition, Hassett and Thompson (1996) and Heebink and Hassett (2001) have explained that during the formation of ettringite, several heavy metals, including arsenic, BR, chromium, molybdenum, selenium, and vanadium, can be fixed into the crystalline structure of the mineral ettringite. This formation is used in the reduction or prevention of groundwater pollution. However, it should be investigated whether these industrial wastes will pollute groundwater. 
Arora, S., Aydilek, A.H., \& Class, F. (2005). Fly-ash-amended soils as highway base materials. Journal of Materials in Civil Engineering, 17, 640-649. doi.org/10.1061/(ASCE)0899-1561(2005)17:6(640)

ASTM D 560. (2003). Standard test methods for freezing and thawing compacted soil-cement mixtures. Annual Book of ASTM Standards.

ASTM C 618. (2003). Standard specification for coal fly ash and raw or calcined natural pozzolan for use in concrete. Annual Book of ASTM Standards.

Cetin, B., Aydilek, A.H., \& Guney, Y. (2010). Stabilization of recycled base materials with high carbon fly ash. Resources, Conservation and Recycling. 54, 878-892. doi:10.1016/j.resconrec.2010.01.007

Fauzi, A., Nazmi, W.M., \& Fauzi, U.J. (2011). Engineering quality improvement of kuantan clay subgrade using recycling and reused materials as stabilizer. In The 3rd International Conference on Geotechnical Engineering for Disaster Mitigation and Rehabilitation. Semerang, Indonesia. 500-506.

Firat S., Yılmaz, G., Comert,A.T., \& Sumer, M. (2012). Utilization of Marble Dust, Fly Ash and Waste Sand (Silt-Quartz) in Road Subbase Filling Materials. KSCE Journal of Civil Engineering, 16(7),1143-1151. doi: 10.1007/s12205-012-1526-4.

Firat S., Khatib J.M., Yilmaz G., \& Comert A.T. (2017). Effect of curing time on selected properties of soil stabilized with fly ash, marble dust and waste sand for road sub-base materials. Waste Management \& Research 35(7), 747-756. doi:10.1177/0734242X17705726

Goswami R.K., \& Mahanta C. (2007). Leaching characteristics of residual lateritic soils stabilized with fly ash and lime for geotechnical applications. Waste Management 27, 466-481. doi.org/10.1016/j.wasman.2006.07.006.

Gurbuz, A. (2015). Marble powder to stabilize clayey soils in subbases for road construction. Road Materials and Pavement Design, 16(2), 481-492. doi:10.1080/14680629.2015.1020845.

Hassett D.J., \& Thompson J.S. (1996). Enhanced Ettringite Formation for The Treatment of Hazardous Liquid Waste. United States Patent, Patent No: US5547588A. (https://patents.google.com/patent/US5547588A/en)

Hassini, S. (1992). Some aspects of landfill design. Mediterranean Conference on Environmental Geotechnology. Cesme, Turkey. 137-143.

Heebink, L.V., \& Hassett, D. J. (2001). Coal Fly Ash Trace Element Mobility in Soil Stabilization. International Ash Utilization Symposium. Center for Applied Energy Research, University of Kentucky, Paper 64. Available: http://www.flyash.info/2001/envben2/64heebin.pdf

James, J. \& Pandian, P.K. (2018). Strength and microstructure of micro ceramic dust admixed lime stabilized soil. Revista de la Construcción 17,5-22. doi:10.7764/RDLC.17.1.5

Keshavan, V., Ajith, M., Arun, G., Kumar, M.A., \& Mohamed, J.B.S.N. (2017). Soil Stabilization using Marble Dust and Granite Dust in Clay Soil. International Journal of Engineering Science and Computing, 7(4), 10084-10086.

Koyuncu, H., \& Guney, Y. (2003). Stabilization of borax wastes. First International Conference on Environmental Research and Assessment. Bucharest, Romania, March 23-27.

Mishra, J., Yadav, R.K., \& Singhai, A.K. (2014). Effect of granite dust on index properties of lime stabilized black cotton soil. Int. J. Engg. Res. \& Sci. \& Tech., 3(1),19-23.

Ogbonnaya, I., \& Illoabachie, D.E. (2011). The potential effect of granite dust on the geotechnical properties of Abakaliki clays. Continental J. Earth Sciences, 6(1),23-30.

Thirumalai, R., Babu, S.S., Naveennayak, V., Ragavendra, B., \& Praveenkumar, G. (2017). Stabilization of black cotton soil using granite waste and quarry dust. International Research Journal of Engineering and Technology, 4(8), 226-229.

Sivapullaiah, P.V. (2016). Stabilization of expansive soil with industrial solid waste. The Master Builder, Indian's premier construction magazine, December 31. Available: http://www.masterbuilder.co.in/ebook/2016/December2016_eBook/index.html.

TS EN 197-1. (Turkish Standard) (2002). Cement - Part 1: Generally cements-compounds, properties and convenient criteria. Publication of Turkish Standard Institution. Available: https://www.tse.org.tr

TS 1900-1. (Turkish Standard). (2006). Methods of testing soils for civil engineering purposes in the laboratory - Part 1: Determination of physical properties. Publication of Turkish Standard Institution. Available: https://www.tse.org.tr

TS 1900-2. (Turkish Standard). (2006). Methods of testing soils for civil engineering purposes in the laboratory - Part 2: Determination of mechanical properties. Publication of Turkish Standard Institution. Available: https://www.tse.org.tr

Verma, A. \& Singh, A. (2017). Strength Improvement of Clayey Soil by using Fly ash and Marble dust. International Journal of Science, Engineering and Technology Research (IJSETR), 6(4), 634-639.

Yoobanpot, N., Jamsawang, P. \& Horpibulsuk, N. (2017). Strength behavior and microstructural characteristics of soft clay stabilized with cement kiln dust and fly ash residue. Applied Clay Science, 141, 146-156. doi.org/10.1016/j.clay.2017.02.028.

Zaman, M., \& Naji, K. (2003). Effect of freeze-thaw cycles on class C fly ash stabilized aggregate base. Proceedings of the 82nd Annual Meeting of Transportation Research Board (TRB). Washington, DC.

Zhang, Y., Guo, Q., Li, L., Jiang, P., Jiao, Y., \& Cheng, Y. (2016). Reuse of Boron Waste as an Additive in Road Base Material. Materials (Basel, Switzerland), 9(6), 416. doi.org/10.3390/ma9060416. 
Zorluer, I., \& Demirbas, A. (2013). Use of marble dust and fly ash in stabilization of base material. Science and Engineering of Composite Materials, 20(1), 47-55. doi.org/10.1515/secm-2012-0074.

Zorluer, I., Gurer, C., Cetin, S., \& Gucek, S. (2013). Usability in the stabilization of the base layer of the granite waste. 6. National Asphalt Symposium. November 27-28. Ankara, Turkey. 222-229.

Zorluer, I., \& Gucek, S. (2014). The effects of marble dust and fly ash on clay soil. Science and Engineering of Composite Materials, 21(1), 59-67. doi.10.1515/secm-2012-0100.

Zorluer, I., \& Gucek, S. (2017a). Usage of fly ash and waste slime boron for soil stabilization. Periodicals of Engineering and Natural Sciences. 5(1) Special Issue (Recent Topics in Environmental Science). 51-54. doi.org/10.21533/pen.v5i1.74.

Zorluer, I., \& Gucek, S. (2017b). Usage of fly ash and granite dust for soil stabilization. 5th International Symposium on Innovative Technologies in Engineering and Science. 29-30 September. Baku - Azerbaijan. 532-538. 